\title{
Stability of frozen marolo pulp during storage
}

\author{
Clarissa DAMIANI ${ }^{1 \star}$, Flávio Alves da SILVA ${ }^{1}$, Moacir Evandro LAGE ${ }^{2}$, Douglas Endrigo Perez PEREIRA³, \\ Fernanda Salamoni BECKER ${ }^{4}$, Eduardo Valério de Barros VILAS BOAS ${ }^{4}$
}

\begin{abstract}
Marolo, also known as araticum or head-to-black, is a globular berry, a species native to the Brazilian savannah. The aim of this study was to evaluate the physical, chemical, and microbiological stability of frozen marolo pulp during 12 months of frozen storage. It was observed that the levels of ash (0.28-0.22\%), protein (0.77-0.71\%), lipids (1.75-1.73\%), carbohydrates (12.1-10.15\%), calorie (67.23-59.01 kcal), sucrose (2.50-1.29\%), citric acid (435.63-197.5 $\mu$ g.g $\left.\mathrm{g}^{-1}\right)$, tartaric acid (4.38-1.88 $\left.\mu \mathrm{g} \cdot \mathrm{g}^{-1}\right)$, acetic acid (470.38-279.25 $\left.\mu \mathrm{g} \cdot \mathrm{g}^{-1}\right)$, ascorbic acid $\left(3.00-0.00 \mu \mathrm{g} \cdot \mathrm{g}^{-1}\right)$, total pectin $(0.67-0.39 \%)$, pH $(3.88-3.83)$, and $\mathrm{b}^{\star}$ chromaticity coordinates (24.85-20.53) decreased reduced during storage, whereas the levels of moisture (85.10-87.19\%), color parameters $\left(\mathrm{L}^{\star} 58.89-62.62\right.$ and $\left.\mathrm{a}^{\star} 5.37-7.86\right)$, reducing sugars (4.53-5.62\%), total soluble sugars (7.1-7.36\%), soluble solids $\left(7.0-8.4{ }^{\circ} \mathrm{Brix}\right)$, total acidity (0.9-1.0\%), malic acid (514.13-781.25 $\left.\mu \mathrm{g} \cdot \mathrm{g}^{-1}\right)$, soluble pectin $(0.16-0.24 \%)$, and antioxidant $(6.85-37.35 \%$ of DPPH discoloration) increased over the one-year of storage period. According to the physical, chemical, and microbiological parameters assessed, the product can be stored for 12 months without loss of quality with addition of citric acid as a preservative.
\end{abstract}

Keywords: savanna fruits; Annona crassiflora Mart.; shelf-life.

\section{Introduction}

Brazil is the country with the highest biological diversity in the planet; its rich flora and fauna are distributed in the Brazilian geographic space into six main biomes: Savanna, Fields and Southern Forests, Atlantic Forest, Caatinga, Rain Forest, and Pantanal (RIBEIRO; WALTER, 1998). Species native to the Brazilian savanna have the potential for adaptation to the environment and a lot of good potential uses. These species reproduce mainly through seeds ensuring the maintenance of genetic diversity. The Brazilian Savanna has a great number of edible fruits that have long been consumed by human populations. These native fruits are consumed both raw and in the form of sweet desserts, cakes, breads, cookies, jams, and liqueurs (ALMEIDA, 1998).

Maroleiro (Annona crassiflora Mart), a fruit species unique to the Brazilian savanna, which is also known as Marolo, araticum, or head-to-black, is green before ripening and pale brown when mature (LORENZI, 1998). The fruit weighs from 0.5 to $5 \mathrm{~kg}$ and contains 60-190 cone-shaped buds, which usually involve the seeds. On average, the yield is from 5 to 20 fruits per plant, reaching up to 40 fruits yielding $50-60 \%$ of pulp. Its flesh is slightly sweet and has a pleasant aroma, and it can vary in color from white to yellow; the yellow-flesh fruit is better accepted in the consumer market due its more pronounced flavor and aroma (CARVALHO, 2002).

According to Franco (1999), 100g of Marolo contain $453 \mu \mathrm{g}$ thiamine, $100 \mu \mathrm{g}$ riboflavin, $2.675 \mathrm{mg}$ niacin, $10.3 \mathrm{~g}$ carbohydrate, $0.4 \mathrm{~g}$ protein, $1.6 \mathrm{~g}$ fat, $52 \mathrm{mg}$ calcium, $24 \mathrm{mg}$ phosphorus, and $2.3 \mathrm{mg}$ iron and $52 \mathrm{kcal}$. However, this species is at risk of extinction due to deforestation in the Brazilian Savanna. Marolo fruit was physically and chemically characterized by Damiani et al. (2011), and the results obtained for the Marolo pulp were: moisture (70.56 g.100 $\mathrm{g}^{-1}$ ), ash $\left(0.54\right.$ g. $\left.100 \mathrm{~g}^{-1}\right)$ protein $\left(1.99 \mathrm{~g} .100 \mathrm{~g}^{-1}\right)$, lipids $\left(2.36 \mathrm{~g} .100 \mathrm{~g}^{-1}\right)$, total carbohydrates $\left(24.55 \mathrm{~g}^{1} 100 \mathrm{~g}^{-1}\right)$, total soluble sugars (127.4 g.100 $\left.\mathrm{g}^{-1}\right), \mathrm{pH}$ (4.49); soluble solids (21.4 $\left.{ }^{\circ} \mathrm{Brix}\right)$, and antioxidant potential (34.29 DPPH discoloration. $100 \mathrm{ml}^{-1}$ ). The predominant mineral is magnesium $\left(350 \mathrm{mg} \cdot \mathrm{kg}^{-1}\right)$, followed by phosphorus (220 mg. $\mathrm{kg}^{-1}$ ), and the predominant organic acids are malic $\left(76.68 \mu \mathrm{g} . \mathrm{g}^{-1}\right)$ and citric acid $\left(23.52 \mu \mathrm{g} . \mathrm{g}^{-1}\right)$.

The diversity of fruits in Brazil has leveraged the agribusiness sector since the demand for regional products in large urban centers has been growing fast. Aware of the public's expectations and demands of the consumer market, the food industry seeks to improve its products. To expand the domestic and international fresh fruit market, Brazil relies upon the consumer interest by manufactured goods in the form of juices, pulps, jams, jellies and others (LICODIEDOFF et al., 2010).

Although marolo has been consumed for many years, only few people have access to this fruit since it is only found in some regions of the country and is available a few months a year. Due to the fact that the post-harvest shelf-life of Marolo is relatively short under refrigeration, even when combined with the use of modified atmosphere packaging (SOARES JUNIOR et al., 2007), the manufacturing of frozen pulp is not only an alternative to

\footnotetext{
Received 4/3/2013

Accepted 9/19/2013 (006064)

Department of Food Engineering, School of Agronomy and Food Engineering, Federal University of Goias - UFG, Rod. Goiânia, Km 0, Nova Veneza, CEP 74001-970, Goiânia, GO, Brazil, e-mail: damianiclarissa@hotmail.com

2 School of Veterinary, Federal University of Goias - UFG, Goiânia, GO, Brazil

${ }^{3}$ Laboratory of Food Chemistry and Biochemistry, School of Pharmacy, Federal University of Goias - UFG, Goiânia, GO, Brazil

${ }^{4}$ Department of Food Science, Federal University of Lavras - UFLA, Lavras, MG, Brazil

${ }^{*}$ Corresponding author
} 
solve this food technology problem, but it can also add value to the fruit, ensuring consumption throughout the year and making the fruit available across the country.

The market for frozen fruit pulp has shown reasonable growth with the current available technology, showing great market potential due to the variety of fruits with quite nice exotic tastes (SILVA et al., 2010). In usual storage conditions $\left(-18^{\circ} \mathrm{C}\right)$, the microbial activity in frozen products is fairly inhibited since most microorganisms do not grow at temperatures below $-10^{\circ} \mathrm{C}$. The water-ice transition has the advantage of fixing the tissue structure and the water under the form of crystals, making it unavailable as solvent and/or as reactant and the diffusion of chemical compounds in the tissue is very slow, which associated with a decrease in temperature, contributes to the decrease in the speed of most reactions (ARAÚJO et al., 2007). However, changes can occur even at temperatures below $0{ }^{\circ} \mathrm{C}$, and the speed at which the food was frozen and the temperature stability during storage are factors that influence food stability (SILVA et al., 2010).

Therefore, the aim of this study was to use marolo fruit to make frozen marolo pulp, thus adding value to this fruit which is typical of the Brazilian savanna and to evaluate the physical, chemical, and microbiological stability of the pulp during storage $\left(-18^{\circ} \mathrm{C}\right)$.

\section{Materials and methods}

Marolo fruits harvested in 2010 in the State of Minas Gerais, Brazil were used. After selection, the fruits were washed to remove surface contamination, rinsed, and submerged in a 100 $\mu \mathrm{l} . \mathrm{L}^{-1}$ sodium hypochlorite solution for 20 minutes.

The fruits $(40 \mathrm{~kg}$ ) were then submitted to pulping using a depulper (Bonina, Model 0.25 DF, Itabuna, Brazil); citric acid (1\%) was added to the pulp obtained (18 kg), which was then pasteurized $\left(95^{\circ} \mathrm{C} / 5\right.$ minutes $)$ in a $100 \mathrm{~mL}$ stainless container with dimensions $\times 5 \times 1 \mathrm{~cm}$, hot packed $\left(85^{\circ} \mathrm{C}\right)$ in $12 \times 26 \mathrm{~cm}$ low-density polyethylene (LDPE) bags of $0.20 \mathrm{~mm}$ thickness and capacity of $100 \mathrm{~g}$, cooled in an ice bath, and stored at $-18^{\circ} \mathrm{C}$ in a domestic freezer (Electrolux, Model H400, Curitiba, Brazil) for 12 months for stability analysis. The pulp samples were thawed in the package after $0,2,4,6,8,10$, and 12 months of storage by immersion in a water bath at $25^{\circ} \mathrm{C}$ for 6 minutes and evaluated for physical, chemical, and microbiological characteristics, namely: moisture, ash, protein, lipids, total carbohydrates, caloric value, total soluble sugars, reducing sugars, sucrose, soluble solids, total pectin, soluble pectin, antioxidant compounds, phenolics, $\mathrm{pH}$, organic acids, color $\left(L^{*}, a^{*}, b^{*}\right)$ and filamentous fungi and yeasts, coliforms at 35 and $45^{\circ} \mathrm{C}$, and Salmonella $s p$. The analyses were carried out in triplicate.

Moisture $\left(105^{\circ} \mathrm{C}\right)$, ash (incineration at $\left.550^{\circ} \mathrm{C}\right)$, protein $(\mathrm{N}$ $\mathrm{x}$ 0.65), lipids, $\mathrm{pH}$, soluble solids, total soluble sugars, reducing sugars, and sucrose contents were determined according to the Association of Official Analytical Chemists - AOAC (ASSOCIATION..., 1997), and the results were expressed as percentages. Total and soluble pectin contents were extracted according to McCready and McComb (1952) and determined by the colorimetric method according to Bitter and Muir (1962), total carbohydrate content according to Dubois et al. (1956), and the total caloric value was estimated using the Atwater conversion factors according to Wilson, Santos and Vieira (1982); the results were expressed as percentage and kcal, respectively.

Organic acids were extracted according to Bazimarakenga, Simard and Leurox (1995), modified by Silva et al. (2001), and the identification and quantification of citric, malic, tartaric, acetic, and ascorbic acids were performed by HPLC (High Performance Liquid Chromatography) using a Shimadzu chromatograph, model CLASS LC 10 (Kyoto, Japan), equipped with SPD-M10A UV detector, at a wavelength of $230 \mathrm{~nm}$ using a C-18 reverse phase column $(150 \times 4.6 \mathrm{~mm} \mathrm{ID,} 3 \mu \mathrm{m})$. The sample injection volume was adjusted to $20 \mu \mathrm{L}$, using water containing $0.1 \%$ phosphoric acid as the mobile phase at the flow rate of $1 \mathrm{~mL} \cdot \mathrm{min}^{-1}$. Identification was based on retention times and co-chromatography absorption spectra, whenever necessary. Quantification was performed based on a seven-point external calibration curve for each organic acid. The following concentrations were used to draw the standard curve: $0.8,0.5$, 0.25 , and $0.01 \mathrm{mg} \cdot \mathrm{mL}^{-1}$ for citric, malic, tartaric, and ascorbic acid, respectively; the other six points were obtained by dilution in series with the mobile phase (1/1). Calibration curves were also used to evaluate the linearity range. All samples including the mobile phase were filtered through a micron membrane filter (0.45 micron pore (Millipore JBR61022 and HAWP04700). The results were expressed as $\mu \mathrm{g} \cdot \mathrm{g}^{-1}$.

The antioxidant capacity was determined by the DPPH method as described by Brand-Williams, Cuvelier and Berset (1995) and modified by Borguini and Torres (2009). The discoloration degree of the DPPH radical at $517 \mathrm{~nm}$ by the action of antioxidants was measured using a spectrophotometer (Shimadzu, model UV-1601 PC, Kyoto, Japan) in the ethereal, alcoholic, and aqueous extracts with concentration of $0.2 \mathrm{mg} \cdot \mathrm{mL}^{-1}$, and the results were expressed as \% DPPH discoloration. Extractions were performed in triplicate for each sample. Ethereal, alcoholic, and aqueous extracts were obtained from frozen samples using a sequential extraction process for fruits (BORGUINI; TORRES, 2009).

The extraction of alcoholic and aqueous compounds was carried out as described by Genovese et al. (2003) for determination of phenolic compounds using Folin-Ciocalteu reagent. The determination of these phenols was described by Zieliski and Kozowaska (2000), and the results were expressed as mg GAE. $100 \mathrm{~g}^{-1}$.

Color was determined using a Konica Minolta CR-400 colorimeter (Manaus, Brazil) according to the CIE system, measuring $L^{*}, a^{*}$, and $b^{*}$ (observation angle of $10^{\circ}$ and illuminant D65). The $\mathrm{L}^{\star}$ coordinate represents the lightness/ darkness of the pulp, with values ranging from 0 (totally black) to 100 (totally white); $\mathrm{a}^{*}$ coordinate shows values between -80 and +100 , and the extremes correspond to green and red, respectively; and $\mathrm{b}^{*}$ coordinate shows values ranging from -50 to +70 , with intensity from blue to yellow. The readings were made at three different points in each pulp package. 
The microbiological analyses for filamentous fungi and yeasts, coliforms at 35 and $45^{\circ} \mathrm{C}$, and Salmonella sp. followed the methodology proposed by the International Commission on Microbiological Specifications for Foods - ICMSF (INTERNATIONAL..., 1983).

A completely randomized design (CRD) was used, and the influence of seven levels of factor time was evaluated $(0,2,4,6$, 8,10 , and 12 months). Each experimental plot consisted of five packages containing $100 \mathrm{~g}$ of pulp with three replicates each.

The statistical analysis was performed using the SISVAR software (FERREIRA, 2000). After applying the analysis of variance, at significance level of $5 \%(\mathrm{p}<0.05)$, polynomial regression models were selected based on the significance of the F test for each model tested and also by the coefficient of determination.
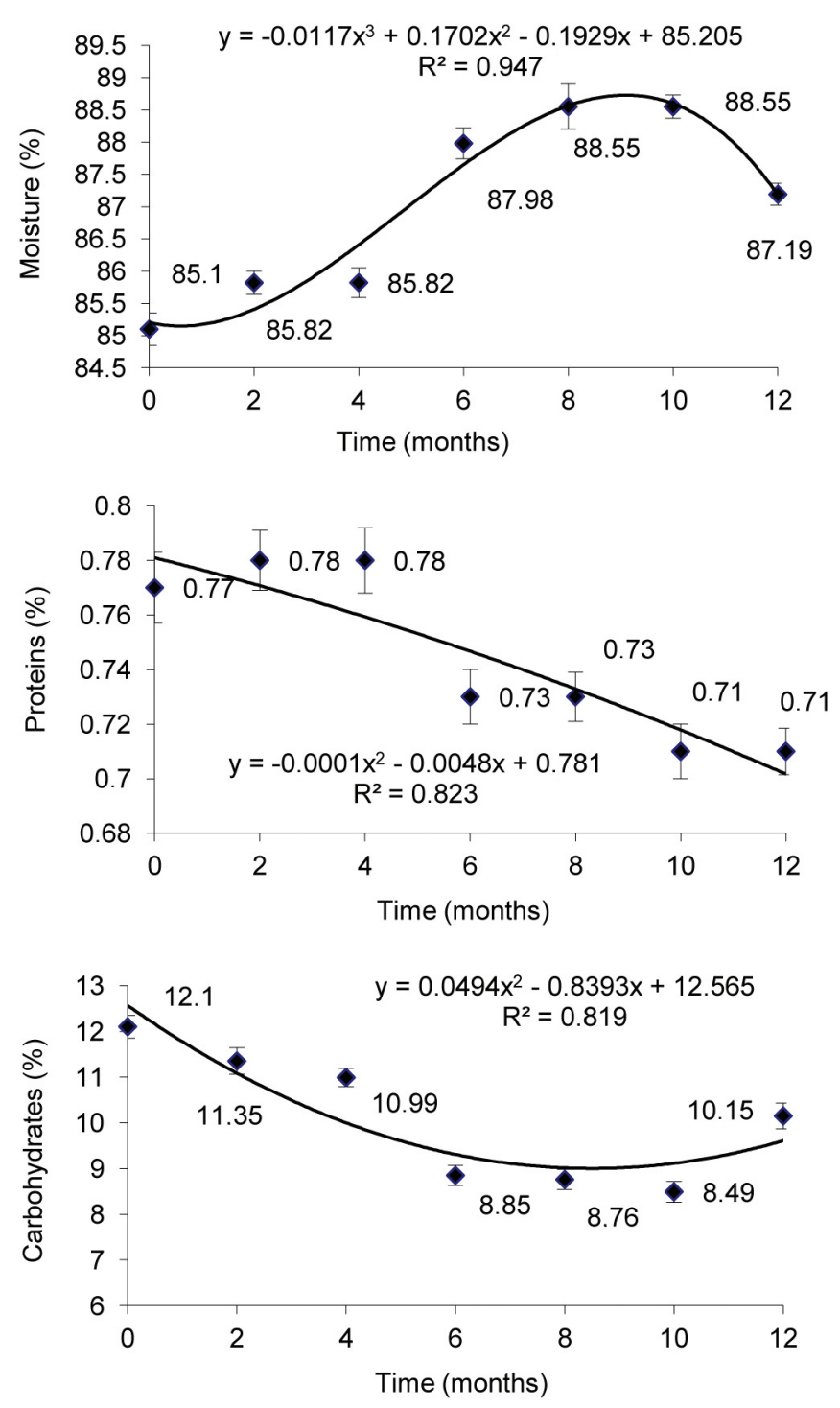

\section{Results and discussion}

Moisture, protein, fat, total carbohydrate contents, ash, and caloric value were influenced by the factor time $(\mathrm{p}<0.05)$ (Figure 1). It was observed that the moisture content increased (2.46\%) throughout the 12 months of storage and with this, the other components of proximal composition tended to decrease. The slow freezing process can damage the cellular structure and release intracellular water, especially free water since, according to Cheftel, Cheftel and Besançon (1989), in an aqueous solution at $-18^{\circ} \mathrm{C}$, part of the water remains in the liquid state and can migrate out of the cell, thus increasing its content in the frozen product.

A factor that causes changes in the chemical constituents of the marolo pulp is the freezing process because although the effect of temperature is to reduce reaction rates, the overall
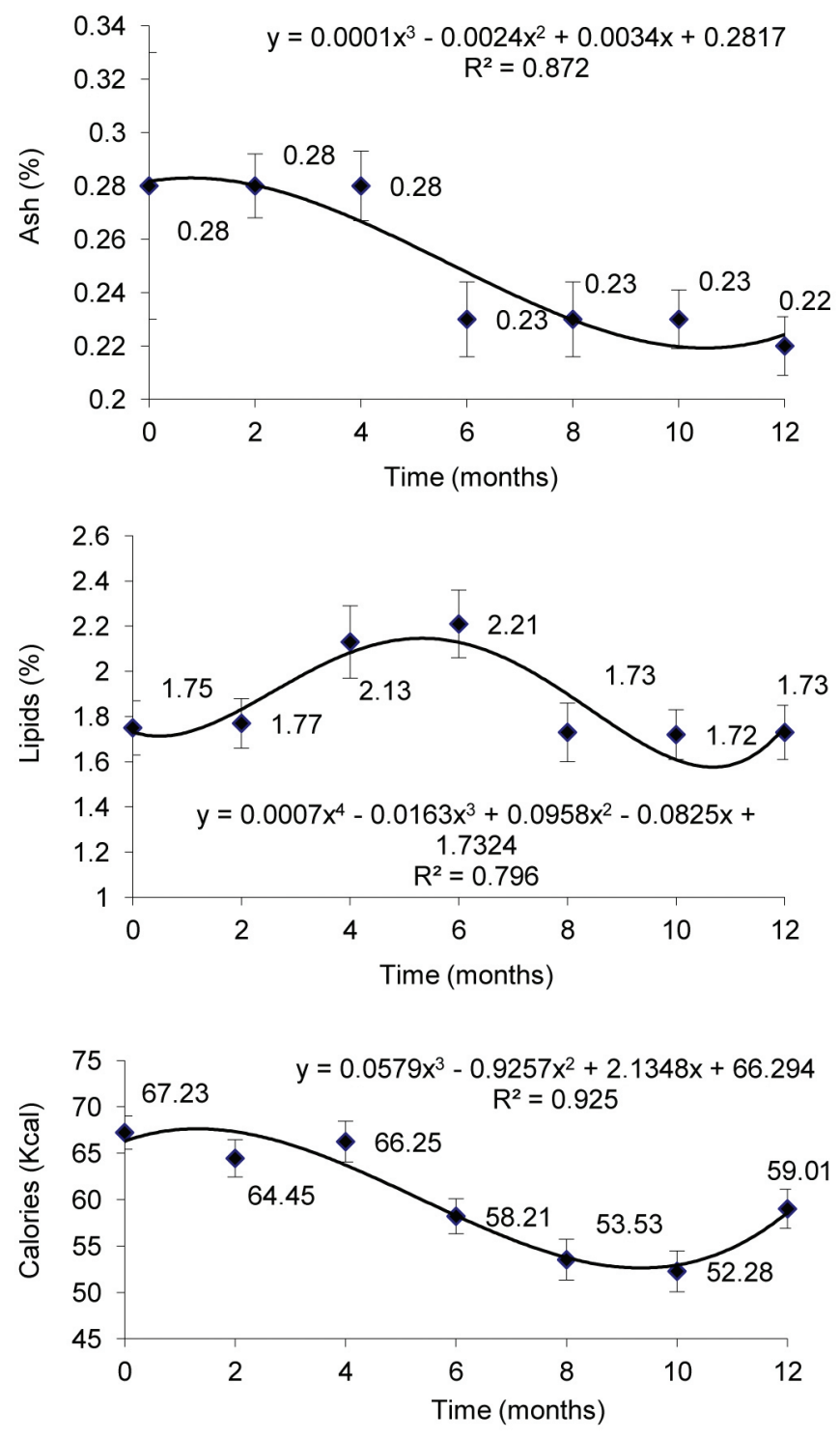

Figure 1. Proximal composition (wet basis) of frozen marolo pulp $\left(-18^{\circ} \mathrm{C}\right)$ during 12 months of storage. 
reaction rate can increase or decrease at a rate less than expected as a result of the higher reactant concentrations that result from freeze concentration (DAMODARAN; PARKIN; FENNEMA, 2010).

The levels of reducing sugars, sucrose, total soluble sugars, soluble solids, and total and soluble pectin were also influenced by storage time $(\mathrm{p}<0.05)$.

Figure 2 shows that among the total soluble sugars, frozen marolo pulp showed lower sucrose levels than those of reducing sugars. During storage, sucrose may have been hydrated and undergone inversion of its molecule into glucose and fructose, which was induced by the low $\mathrm{pH}$ of the medium (Figure 3). In acid medium ( $\mathrm{pH}<7.0)$, sucrose undergoes reverse reaction forming equal amounts of glucose and fructose (BRIGHENTI et al., 2011). Damiani et al. (2013), Pina et al. (2003) and Torrezan (1996) also observed the inversion of sucrose during storage of frozen araça pulp $\left(-18^{\circ} \mathrm{C}\right)$, mango
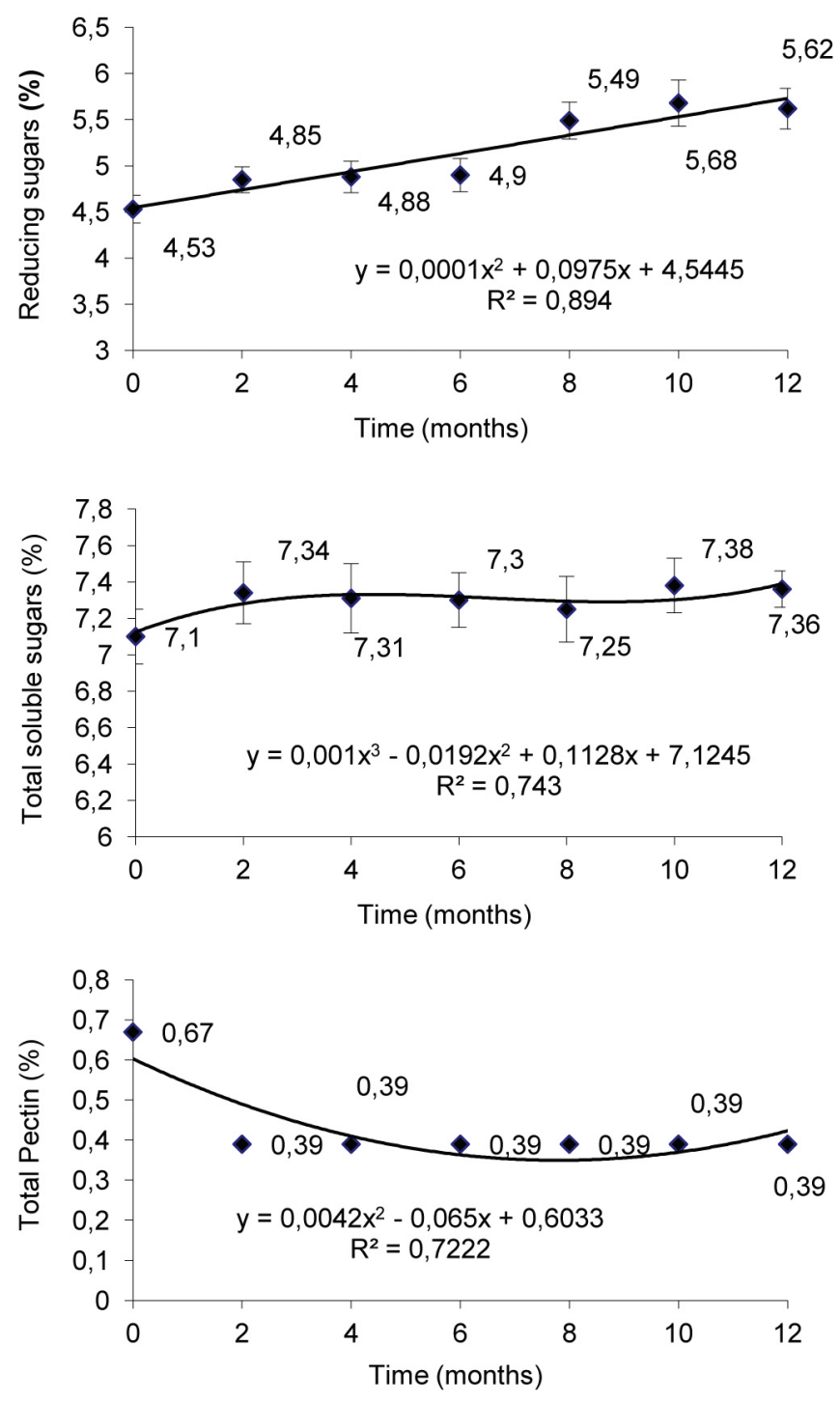

chunks $\left(28^{\circ} \mathrm{C}\right)$, and guava pulp preserved by combined methods.

According to Damiani et al. (2011), fresh marolo pulp showed $16.68 \%$ of total soluble sugars, of which $12.38 \%$ was reducing sugars and $4.11 \%$ sucrose. The reduction in the total soluble sugars in relation to the fresh frozen pulp may have been due to the caramelization process during thermal processing, fruit ripening stage, and climatic characteristics.

The soluble solids represent the levels of soluble sugars, organic acids, and other minor constituents present in the sample (HOBSON; GRIERSON, 1993). The increase in the soluble solids content in the frozen marolo pulp can be related to the slight increase in the total soluble sugars and malic acid contents (Figure 3).

It was observed that, during storage, there was reduction in the total pectin content $(41.79 \%)$ and an increase in the
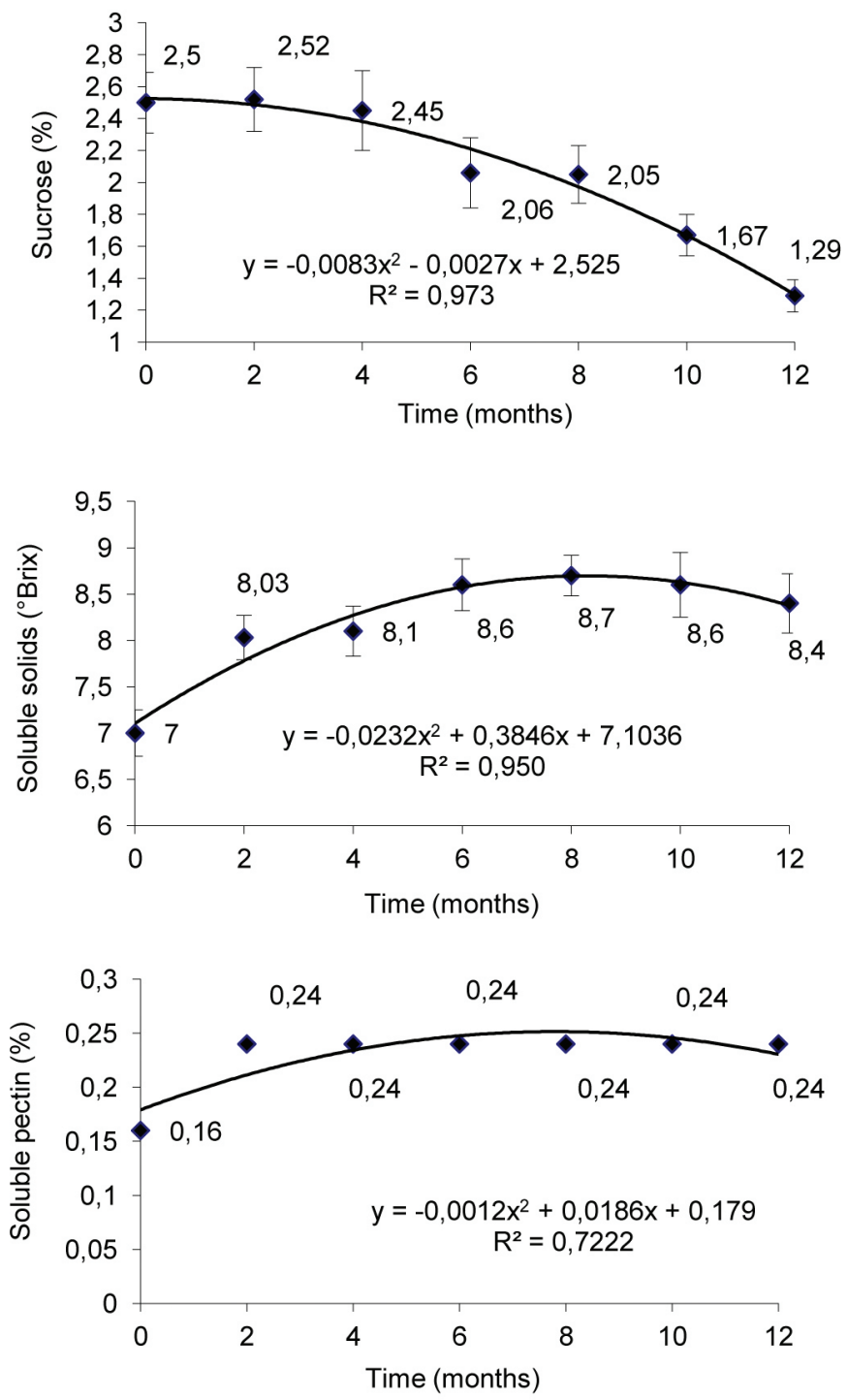

Figure 2. Average contents of reducing sugars (\%), sucrose (\%), total soluble sugars (\%), soluble solids ( ${ }^{\circ}$ Brix), and total and soluble pectin (\%) in frozen marolo pulp $\left(-18^{\circ} \mathrm{C}\right)$ during 12 months of storage. 

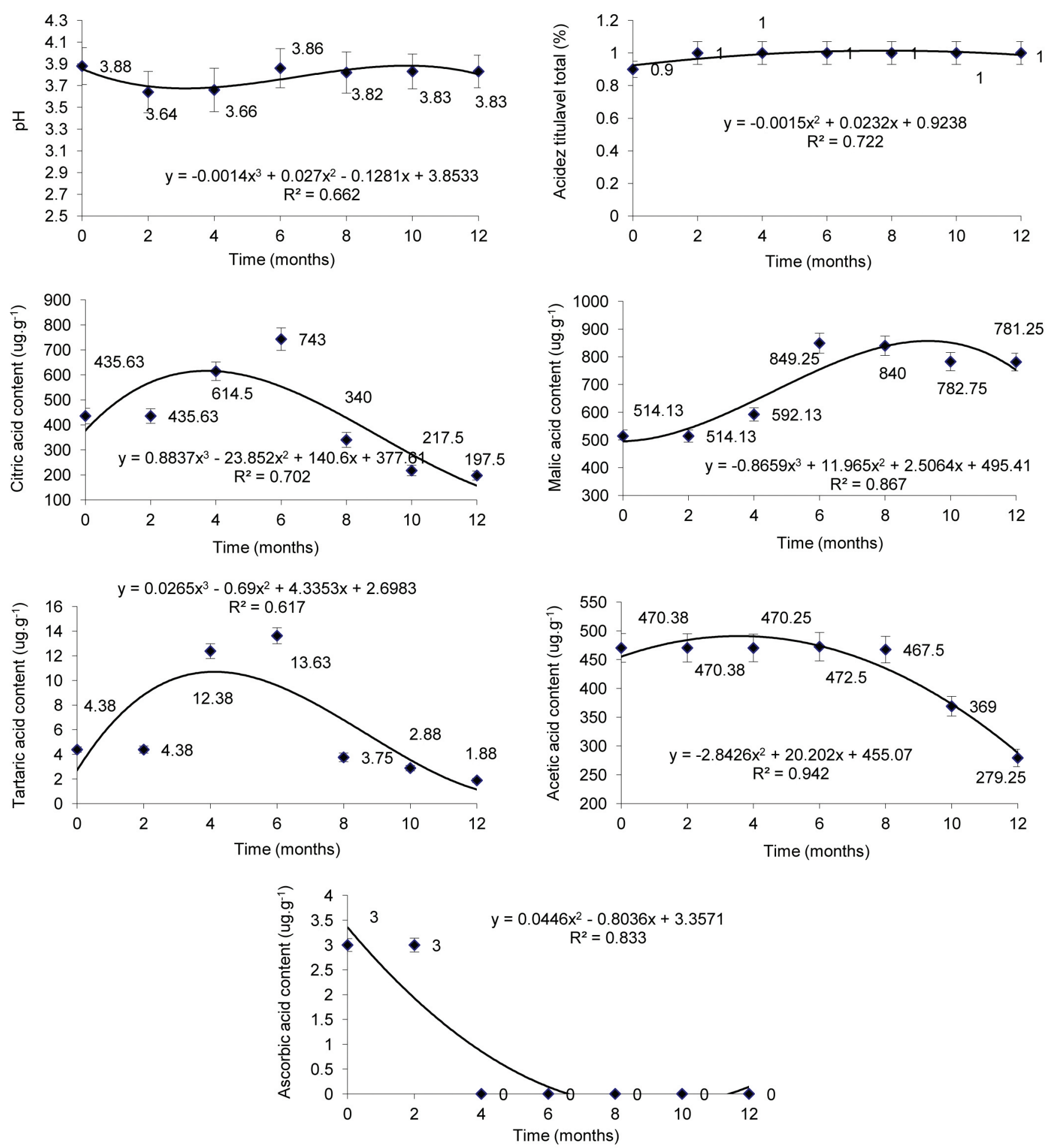

Figure 3. Average values of $\mathrm{pH}(\%)$, titratable acidity (\%), citric, malic, tartaric, acetic, and ascorbic acid ( $\mu$ g. $\left.\mathrm{g}^{-1}\right)$ in frozen marolo pulp $\left(-18^{\circ} \mathrm{C}\right)$ during 12 months of storage.

soluble pectin content (50\%). During the freezing process, there was cellular disintegration leading to the acid hydrolysis of the pectin, which was induced by the low $\mathrm{pH}$ of the medium (Figure 3).

The $\mathrm{pH}$ value and the contents of the citric, malic, tartaric, ascorbic, and acetic acids were influenced by storage time $(\mathrm{p}<$
0.05), unlike the titratable acidity, which remained unchanged during storage (Figure 3).

During storage, there was a reduction of $1.29 \%$ in the $\mathrm{pH}$ value. According to Damodaran, Parkin and Fennema (2010), in the freezing process, the unfrozen phase, i.e., liquid phase that concentrates non-aqueous compounds (carbohydrates, proteins, 
lipids, and organic acids among others) undergoes significant changes leading to an increase or decrease in some parameters such as $\mathrm{pH}$, titratable acidity, and ionic strength, depending on the chemical composition of the product.

The reduction in $\mathrm{pH}$ values may be justified by fungi present in the frozen marolo pulp, which may have consumed soluble sugars through glycolytic pathway producing organic acids other than those identified in this research. Fruits are very susceptible to the attack of fungi due to their high sugar content. Some fungi such as Saccharomyces bayanus, S. cerevisiae, Saccharomyces cerevisiae, Schizosaccharomyces pombe, and S. octosporus are commonly found in frozen pulp (TRINDADE et al., 2002). Saccharomyces and Schizosaccharomyces can come into direct contact with fruit pulp during processing due to the different maturation stages, ripe fruits may have higher concentrations of these species, and they may also be present in the processing equipment in the form of spores, even after cleaning (KURTZMAN; FELL, 1998).

Yeasts and molds were detected in the second month of storage (absent at time zero to $2 \times 10^{3} \mathrm{CFU} \cdot \mathrm{g}^{-1}$ in the $2^{\text {nd }}$ month). After that, these microorganisms were no longer detected, maintaining the frozen pulp stable throughout the entire storage period. This indicates the presence of thermo-resistant spores, followed by growth inhibition by reducing the $\mathrm{pH}$ of the medium (Figure 3). Thermo-resistant fungal spores not only endure the temperatures used in the thermal processing of juices and fruit products (KOTZEKIDOU, 1997), but they are also activated by heat (BEUCHAT, 1986) leading to enhanced germination and growth in the final product (MURDOCK; HATCHER, 1978). The presence of organic acids can also enhance the thermal resistance of these microorganisms (SPLITTSTOESSER; SPLITTSTOESSER, 1977). The thermo-resistant filamentous fungi species most frequently involved are Byssochlamys nivea, Byssochlamys fulva, Neosartorya fischeri and Talaromyces flavus (TOURNAS, 1994).

Brazilian law establishes limits for the presence of filamentous fungi and/or yeasts in fruit pulp submitted to heat treatment of $2 \times 10^{3} \mathrm{CFU}^{-g^{-1}}$ (BRASIL, 2000). The presence of these microorganisms can cause physical, chemical, and sensory changes in the product, even when they are microbiologically stable. The presence of Salmonella sp. and total $\left(35^{\circ} \mathrm{C}\right)$ and thermo-tolerant coliforms $\left(45^{\circ} \mathrm{C}\right)$ was not detected thus proving the efficiency of good manufacturing practices during the processing of frozen marolo pulp.

Regarding the organic acids, the contents of citric, ascorbic, tartaric, and acetic acids decreased during storage, possibly as a result of their consumption due to metabolic activity of fungi and/or yeasts in the $2^{\text {nd }}$ month of the storage. These microorganisms may have synthesized malic acid, explaining the slight reduction in $\mathrm{pH}$ and the increase of this organic acid. The concentration of citric acid was higher due to its incorporation to reduce the pulp's $\mathrm{pH}$ during processing.

The frozen marolo pulp showed lower ascorbic acid levels in the beginning of storage, reducing to zero after the sixth month
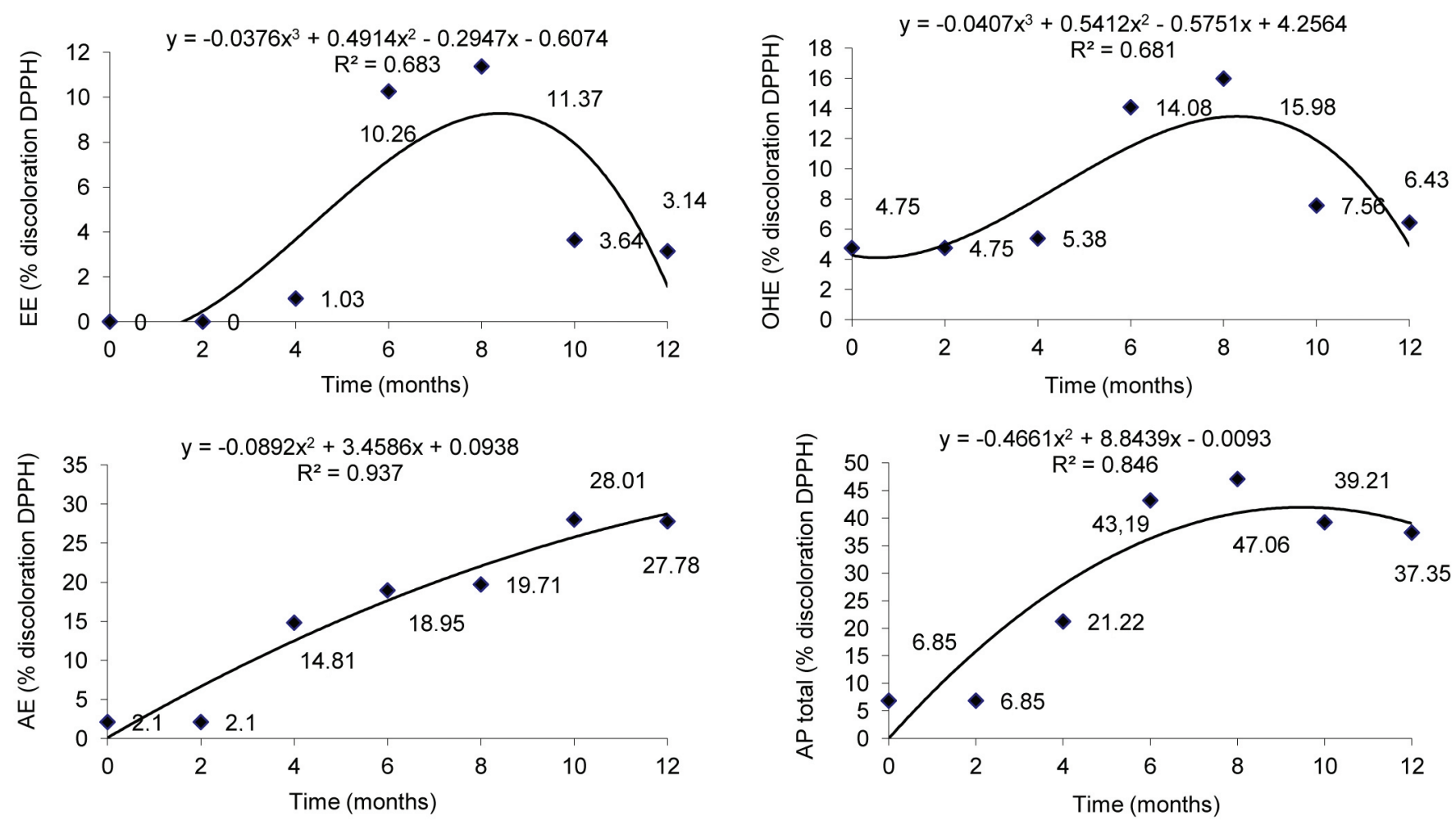

Figure 4. Total antioxidant potential (AP), ethereal extract (EE), ethanol extract (OHE), and aqueous extract (AE), expressed as the \% of decolorization of the DPPH radical in the frozen marolo pulp $\left(-18^{\circ} \mathrm{C}\right)$ during 12 months of storage. Standard $\mathrm{BHT} 0.05 \mathrm{mg} \cdot \mathrm{mL}^{-1}=96.27 \%$ and $0.1 \mathrm{mg} \cdot \mathrm{mL}^{-1}=100 \%$. 

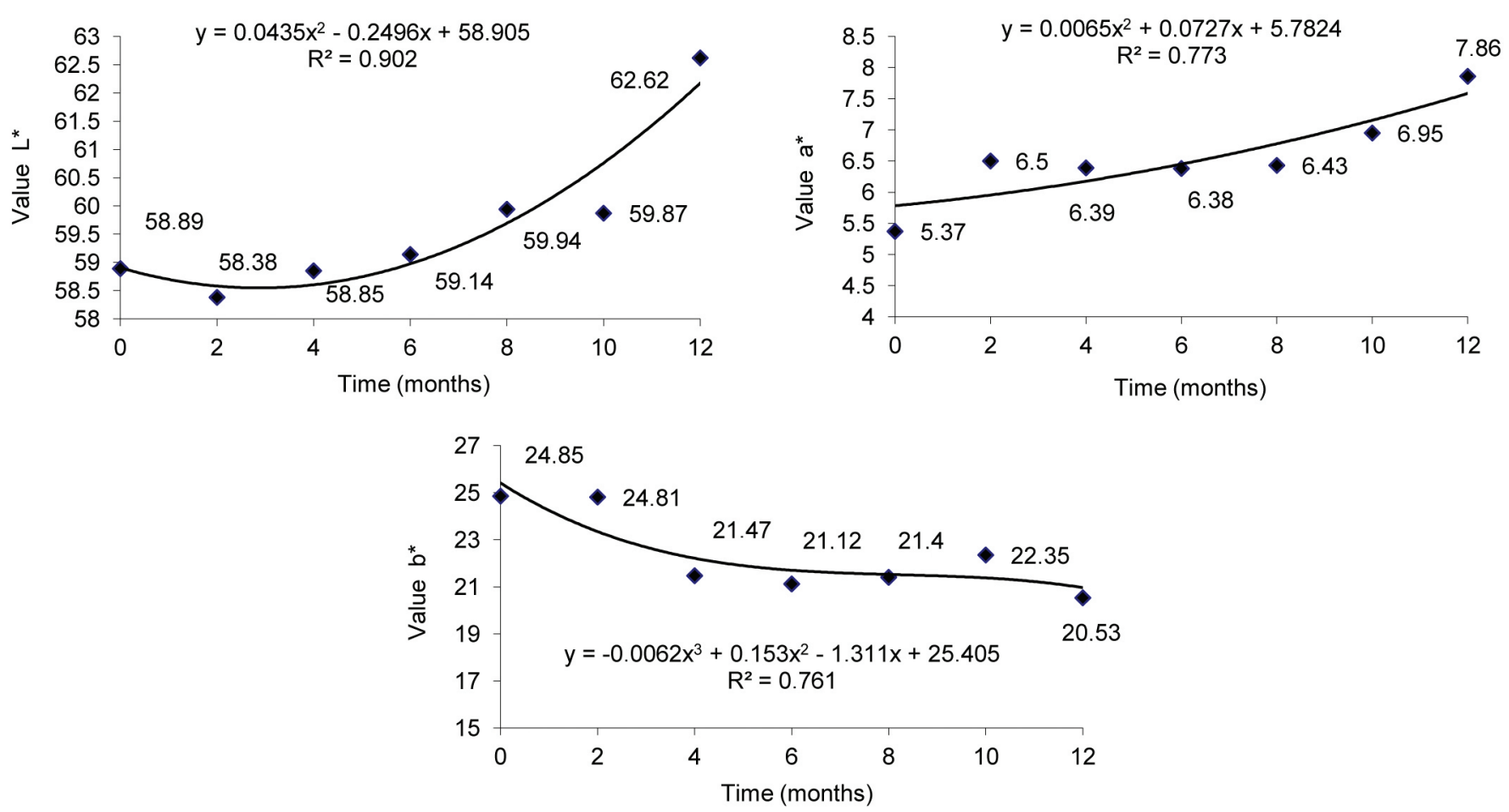

Figure 5. Color parameters $\left(\mathrm{L}^{\star}, \mathrm{a}^{\star}\right.$ and $\left.\mathrm{b}^{\star}\right)$ of frozen marolo pulp $\left(-18^{\circ} \mathrm{C}\right)$ during 12 months of storage.

of storage. Yamashita et al. (2003) reported a reduction of $3.00 \%$ in the ascorbic acid content of acerola pulp frozen at -12 and $-18^{\circ} \mathrm{C}$ for a period of 4 months, respectively.

According to Damiani et al. (2011), fresh marolo pulp had $294.00 \mu \mathrm{g} . \mathrm{g}^{-1}$ citric acid, $958.50 \mu \mathrm{g} \cdot \mathrm{g}^{-1}$ malic acid, and $9.50 \mu \mathrm{g} \cdot \mathrm{g}^{-1}$ ascorbic acid. The reduction in the levels of organic acids in relation to those of fresh fruit can be explained by the thermal processing applied to marolo pulp.

The antioxidant potential was also affected by storage time $(\mathrm{p}<0.05)$, as shown in Figure 4.

The increased antioxidant activity during the storage of frozen marolo pulp can be justified by the slight decrease in the $\mathrm{pH}$ and increase in the malic acid concentrations (Figure 3), observed in the $2^{\text {nd }}$ month of storage. Patthamakanokporn et al. (2008) studied guava extracts stored at $5{ }^{\circ} \mathrm{C}$ and also observed a significant increase in the antioxidant activity, from 120 to $190 \%$ during three months of storage.

According to Damiani et al. (2011), in the fresh fruit pulp, the DPPH reduction values were $34.29 \%$ (total), of which $11.18 \%$ were found in the ether extract, $5.01 \%$ in the alcoholic extract, and $18.10 \%$ in the aqueous extract. These values are higher than those observed in the frozen marolo pulp in the present study, possibly due to the addition of citric acid to the fresh marolo pulp and increment of malic acid during storage of the frozen pulp.

The color parameters were also influenced by storage time $(\mathrm{p}<0.05)$, as shown in Figure 5. The $\mathrm{L}^{\star}$ value and the $\mathrm{a}^{\star}$ and $\mathrm{b}^{*}$ coordinates indicated that there was a slight variation in the color of marolo pulp during the 12 months of storage, which are less likely to become dark, indicating the efficiency of the pasteurization process in enzyme inactivation and the use of citric acid as acidulant. Aquino, Móes and Castro (2011) studied the stability of acerola fruits frozen by cryogenic methods and observed an increase in the $L^{*}$ value and reduction in the $b$ ${ }^{*}$ value over a 2-month storage period.

In the fresh fruit pulp, these parameters showed values of 70.92 for $\mathrm{L}^{\star}, 2.17$ for $\mathrm{a}^{\star}$, and 33.90 for $\mathrm{b}^{\star}$ (DAMIANI et al., 2011), indicating that there was browning in the frozen marolo pulp when compared to pulp of the fresh fruit. The reduction in these values in the frozen pulp is justified by the processing since the frozen pulp was submitted to heat treatment and incorporation of oxygen, which led to the degradation of pigments such as chlorophyll.

\section{Conclusions}

Marolo frozen pulp with the addition of citric acid can be stored for a period of 12 months at $-18{ }^{\circ} \mathrm{C}$ with minor changes in the physicochemical parameters without affecting its microbiological quality, as recommended by standard of Brazilian legislation.

\section{Acknowledgements}

This study was supported by CNPq, CAPES, and FAPEMIG. 


\section{References}

ALMEIDA, S. P. Cerrado: aproveitamento alimentar. Planaltina: Embrapa, 1998. 188 p.

AQUINO, M. C. M. S.; MÓES, R. S.; CASTRO, A. A. Estabilidade de ácido ascórbico, carotenóides e antocianinas de frutos de acerola congelados por métodos criogênicos. Brazilian Journal of Food Technology, v. 14, n. 2, p. 154-163, abr./jun. 2011. http://dx.doi. org/10.4260/BJFT2011140200020

ARAÚJO, P. G. L. et al. $\beta$-caroteno, ácido ascórbico e antocianinas totais em polpa de frutos de aceroleira conservada por congelamento durante 12 meses. Ciência e Tecnologia de Alimentos, v. 27, n. 1, p. 104-107, jan./mar. 2007. http://dx.doi.org/10.1590/S010120612007000100018

ASSOCIATION OF OFFICIAL ANALYTICAL CHEMISTS - AOAC. Official Methods of Analysis of Association of Official Analytical Chemists. Arlington: Ed. Helrich, 1997. 1850 p.

BAZIMARAKENGA, B.; SIMARD, R. R.;LEUROX, G. D. Determination of organic acids in oil extracts by ion chromatography. Soil Biology and Biochemistry, v. 27, p. 349-356, mar. 1995. http://dx.doi. org/10.1016/0038-0717(94)00178-4

BEUCHAT, L. R. Extraordinary heat resistance of Talaromyces flavus and Neosartorya fischeri ascosporos in fruit products. Journal of Food Science, v. 51, n. 6, p. 1506-1510, nov. 1986. http://dx.doi. org/10.1111/j.1365-2621.1986.tb13846.x

BITTER, V.; MUIR, H. M. A modified uronic acid carbazole reaction. Analysis Biochemistry, v. 34, n. 4, p. 330-334, 1962. http://dx.doi. org/10.1016/0003-2697(62)90095-7

BORGUINI, R. G.; TORRES, E. F. S. Tomatoes and tomato products as dietary sources of antioxidants. Food Reviews International, v. 25, p. 313-325, 2009. http://dx.doi.org/10.1080/87559120903155859

BRAND-WILLIAMS, W.; CUVELIER, M. E.; BERSET, C. Use of a free radical method to evaluate antioxidant activity. LebensmittelWissenschaft Technologie, v. 28, n. 1, p. 25-30, 1995.

BRASIL. Instrução Normativa n. 1, de 07 de janeiro de 2000. Regulamento técnico geral para fixação dos padrões de identidade e qualidade para polpa de fruta. Diário Oficial da República Federativa do Brasil, Brasília, DF, 10 jan. 2000. Seção 1, p. 54.

BRIGHENTI, D. M. et al. Inversão da sacarose utilizando ácido cítrico e suco de limão para preparo de dieta energética de Apis mellifera LINNAEUS, 1758. Ciência e Agrotecnologia, v. 35, n. 2, p. 297-304, mar./abr. 2011. http://dx.doi.org/10.1590/S141370542011000200010

CARVALHO, J. A. Marolo: o doce sabor do cerrado; sugestões de cultivo. Machado: Folha Machadense, 2002.

CHEFTEL, J. C.; CHEFTEL, H.; BESANÇON, P. Metodos de conservation. In: CHEFTEL, J. C.; CHEFTEL, H.; BESANÇON, P. (Ed.). Introduction a la bioquímica y tecnología de los alimentos. Zaragoza: Acribia, 1989. cap. 7, p. 173-299.

DAMODARAN, S.; PARKIN, K. L.; FENNEMA, O. R. Química de alimentos de Fennema. 4. ed. Porto Alegre: Artmed, 2010. 900 p.

DAMIANI, C. et al. Characterization of fruits from the savanna: Araça (Psidium guinnensis Sw.) and Marolo (Annona crassiflora Mart.). Ciência e Tecnologia de Alimentos, v. 31, n. 3, p. 723-729, jul./ set. 2011. http://dx.doi.org/10.1590/S0101-20612011000300026

DAMIANI, C. et al. Changes in the physicochemical and microbiological properties of frozen araça pulp during storage. Ciênc. Tecnol. Aliment., Campinas, v 33(Supl. 1): 19-27, fev. 2013
DUBOIS, M. et al. Colorimetric method for determination of sugars and related substances. Analytical Chemistry, v. 28, n. 3, p. 350356, 1956. http://dx.doi.org/10.1021/ac60111a017

FERREIRA, D. F. Análises estatísticas por meio do SISVAR para Windows versão 4. 0, São Carlos, S. P, 2000. In: REUNIÃO ANUAL DA REGIÃO BRASILEIRA DA SOCIEDADE INTERNACIONAL DE BIOMETRIA, 2000, São Carlos. Anais... São Carlos: EdUFSCar, 2000. p. 235.

FRANCO, G. Tabela de composição química dos alimentos. 9. ed. São Paulo: Atheneu, 1999. 307 p.

GENOVESE, M. I. et al. Determinação do conteúdo de fenólicos totais em frutas. Revista Brasileira de CiênciasFarmacêuticas, São Paulo, v. 39, n. 3, p. 167-169, 2003.

HOBSON, G. E.; GRIERSON, D. Tomato. In: SEYMOUR, G. B.; TAYLOR, J. E.; TUCKER, G. A. (Ed.). Biochemistry of fruits ripening. London: Champman \& Hall, 1993. cap. 13, p. 405-442.

INTERNATIONAL COMMISSION ON MICROBIOLOGICAL SPECIFICATIONS FOR FOODS - ICMSF. Microrganisms in food. 2. ed. Toronto: University of Toronto, 1983.

KOTZEKIDOU, P. Heat of Byssochlamys nivea, byssochlamys fulva and Neoartorya fischeri isolated from canned tomato paste. Journal of Food Science, v. 62, n. 2, p. 410-412, 1997. http://dx.doi. org/10.1111/j.1365-2621.1997.tb04014.x

KURTZMAN, C. P.; FELL, J. The yeasts - a taxonomic study. 4th ed. Amsterdam: Elsevier Science B. V., 1998.

LICODIEDOFF, S. et al. Avaliação da sinérese em geléia de abacaxi por meio de análise uni e multivariada. Semina: Ciências Exatas e Tecnológicas, v. 31, p. 51-56, 2010.

LORENZI, H. Árvores Brasileiras: manual de identificação e cultivo de plantas arbóreas nativas do Brasil. 2. ed. Nova Odessa: Plantarum, 1998. 384 p.

McCREADY, R. M.; McCOMB, E. A. Extraction and determination of total pectic materials in fruits. Analytical Chemistry, v. 24, n. 12, p. 1986-1988, 1952. http://dx.doi.org/10.1021/ac60072a033

MURDOCK, D. I.; HATCHER, W. S. A simple method to screen fruit juices and concentrates for heat resistant mold. Journal of Food Protection, v. 41, p. 54-256, 1978.

PATTHAMAKANOKPORN, O. et al. Changes of antioxidant activity and total phenolic compounds during storage of selected fruits. Journal of Food Composition and Analysis, v. 21, n. 3, p. 241-248, 2008. http://dx.doi.org/10.1016/j.jfca.2007.10.002

PINA, M. G. M. et al. Processamento e conservação de manga por métodos combinados. Revista Brasileira de Fruticultura, v. 25, n. 1, p. 63-66, Abril 2003.

RIBEIRO, J. F.; WALTER, B. M. T. Fitofisionomias do bioma cerrado. In: EMBRAPA. Cerrado: ambiente e flora. Planaltina: Embrapa, 1998. p. 87-166.

SILVA, V. K. L et al. Estabilidade da polpa do bacuri (Platonia insignis Mart.) congelada por 12 meses. Ciência e Agrotecnologia, v. 34, n. 5, p. 1293-1300, 2010.

SILVA, F. A. et al. Exsudação de ácidos orgânicos em rizosfera de plantas daninhas. Planta Daninha, v. 19, n. 2, p. 193-196, 2001.

SOARES JUNIOR, M. S. et al. Filmes plásticos e ácido ascórbico na qualidade de araticum minimamente processado. Ciência Rural, v. 37, n. 6, p. 1779-1785, 2007.

SPLITTSTOESSER, D. F.; SPLITTSTOESSER, M. C. Ascospores of Byssochlamys fulva compared with those of a heat- resistant 
Aspergillus. Journal of Food Science, v. 42, n. 3, p. 685-688, 1977. http://dx.doi.org/10.1111/j.1365-2621.1977.tb12579.x

TRINDADE, R. C. et al. Yeasts associated with fresh and frozen pulps of Brazilian tropical fruits. Systematic and Applied Microbiology, v. 25, p. 294-300, 2002. Pmid:12353886.

TORREZAN, R. Preservação de polpa de goiaba por métodos combinados. 1996. 211f. Disertação (Mestrado) - Universidade Estadual de Campinas, Campinas, 1996

TOURNAS, V. Heat-resistant fungi of importance to the food and beverage industry. Critical Reviews in Microbiology, v. 20, n. 4 , p. 243-263, 1994. PMid:7857517. http://dx.doi. org/10.3109/10408419409113558
WILSON, E. D.; SANTOS, A. C.; VIEIRA, E. C. Energia. In: DUTRA OLIVEIRA, J. E.; SANTOS, A. C.; WILSON, E. D. Nutrição básica. São Paulo: Savier, 1982.

YAMASHITA, F. et al. Produtos de acerola: estudo da estabilidade de vitamina C. Ciência e Tecnologia de Alimentos, v. 23, n. 1, p. $92-$ 94, 2003. http://dx.doi.org/10.1590/S0101-20612003000100019

ZIELISKI, H.; KOZOWSKA, H. Antioxidant activity and total phenolics in selected cereal grains and their different morphological fractions. Journal of Agricultural and Food Chemistry, Washington, DC, v. 48, n. 11, p. 2008-2016, 2000. 